\title{
Proposals for the stratigraphic positions of the Berriasian - Valanginian and the Valanginian - Hauterivian boundaries
}

\author{
PH. J. HOEDEMAEKER
}

\begin{abstract}
Hoedemaeker, Ph. J.: Proposals for the stratigraphic positions of the Berriasian - Valanginian and the Valanginian - Hauterivian boundaries. Bull. geol. Soc. Denmark, vol. 33, pp. 139-146, Copenhagen, September, 11th, 1984. https://doi.org/10.37570/bgsd-1984-33-12
\end{abstract}

\begin{abstract}
In two previous papers (Hoedemaeker, 1982, 1983) the author proposed to draw the boundary between the Berriasian and the Valanginian at the base of the Timovella alpillensis Subzone, which he described from SE Spain. The correlation of this subzone with the published French zonation is however problematic, because the faunal association of the alpillensis Subzone is unknown from France. He correlated the alpillensis Subzone with the French Berriasella callisto Subzone. In this paper he revised his previous correlation and equated his alpillensis Subzone with the greater upper part of the callisto Subzone. He correlated the lower part of the latter subzone, which probably covers the interval assigned to the callisto Subzone in the Berriasian stratotype, with the uppermost part of his Berriasella picteti Subzone in Spain. The author also proposed $(1982,1983)$ to draw the Valanginian - Hauterivian boundary between the Saynoceras verrucosum and Himantoceras trinodosum Subzones. This proposal is further elucidated in this paper. The two boundaries discussed here coincide with the peaks of two successive global sea level lowstands, well marked in the Vailian global coastal onlap curve as 'Basal Valanginian (131) global unconformity' and the 'Basal Hauterivian (126) global unconformity' (Vail \& Todd, 1981; Ziegler, 1982).
\end{abstract}

Ph. J. Hoedemaeker, National Museum of Geology and Mineralogy, Hooglandse kerkgracht 17, 2312 HS Leiden, The Netherlands. March 28th, 1984.

\section{Introduction with respect to the Berriasian - Valanginian boundary}

In the stratotype of the Berriasian in SE France the Berriasian - Valanginian boundary (between beds 197 and 198) coincides with a severe caesura in the succession of the ammonite faunas. At this boundary the Berriasian ammonite fauna is suddenly, without transition, and practically entirely replaced by a Valanginian ammonite fauna. This suggests the presence of a hiatus, which is also suggested by the lacunas, clear signs of near emersion, or marked reduction of water depth reported by Donze \& Le Hégarat (1965), Le Hégarat \& Remane (1968), Le Hégarat (1971), and Cotillon (1971) from this boundary in the fringe of the 'Fosse vocontienne'. In the Berrias section this hiatus is situated between beds assigned to the Berriasella callisto Subzone and beds assigned to the Tirnovella pertransiens Subzone (in the original sense of le Hégarat \& Remane, 1968, Le Hégarat, 1971, and Thieuloy, 1973).
From SE Spain Hoedemaeker $(1982,1983)$ reported the same succession of ammonite faunas as described by Le Hégarat (1971) and Thieuloy (1979) from SE France except for the callisto Subzone. Instead, between the beds that were assigned to the Berriasella picteti and the $T$. pertransiens subzones quite a different association was found, which he called the Tirnovella alpillensis Subzone. Fifty percent of the ammonite assemblage of the alpillensis Subzone consists of the assemblage that characterizes the callisto Subzone and the other $50 \%$ of renownedly Valanginian ammonites that otherwise would have characterized the pertransiens Subzone, viz. Olcostephanus, Neocomites, Thurmanniceras, and Sarasinella. Within the alpillensis Subzone the typically Berriasian ammonite association rapidly disappears, whereas a typically Valanginian ammonite association begins at its lower boundary and rapidly diversifies and augments in number.

The severe faunal caesura is not there, but is substituted by a gradual though rapid replace- 
ment of the Berriasian fauna by a Valanginian one. The fifty-fifty mixture of Berriasian and Valanginian ammonites is the main characteristic of the alpillensis Subzone, which is therefore well recognizable and well delimitable. Hoedemaeker (1982, 1983) preferred to draw the Berriasian Valanginian boundary at the base of the alpillensis Subzone.

The marked reduction of the bathymetry and the rapid turnover of the ammonite fauna associated with it, was attributed to a global fall of the sea level. This retreat of the sea, which is attended by a rapid decrease and disappearance of many biotopes, corresponds to the 'Basal Valanginian (131) global unconformity', well marked in the Vailian global coastal onlap curve (Vail \& Todd, 1981; Ziegler, 1982).

\section{Correlation of the alpillensis Subzone}

Because of the considerable overlap of the ranges of Berriasella picteti and $B$. jauberti with the range of Tirnovella donzei, which is in contrast to the data of Le Hégarat (1971), it was not clear at the outset where the lower boundary of the callisto Subzone in the section of Los Miravetes in SE Spain should be drawn in terms of ammonite ranges. The author (Hoedemaeker, 1982, 1983) relied therefore mainly on the first appearance of the calpionellid Lorenziella hungarica (in bed $\mathrm{Y}$ 226 of the Miravates section and just below the base of the callisto Subzone in the Berrias section in France), when he correlated the base of the callisto Subzone with the base of the alpillensis Subzone at the top of bed Y 230. This correlation, however, has one serious flaw: the alpillensis Subzone contains a large number of renownedly Valanginian ammonites, whereas the callisto Subzone does not.

Intrigued by the question of where the true allisto assemblage has got to in Spain, the author re-examined the basic data he presented in 1982 and came to realize that, by merely disregarding the presence of $B$. pictetiljauberti (which may be one species), the ammonite assemblage of the topmost 4,5 m of the beds that he assigned to the picteti Subzone is similar to that of the French callisto Subzone: all those ammonites of the picteti Subzone that according to Le Hégarat's definition should no longer be present in the callisto
Subzone, just have disappeared except for rare B. pictetiljauberti, whereas renownedly Valanginian ammonites have not yet appeared.

The relative age of a stratigraphic interval is far better approximated by similar fossil associations composed of many species (ammonites) than by the appearance of only one rare calpionellid species, of which the first timid appearance can easily be missed. Therefore the author changed his previous idea and now prefers to correlate the base of the French callisto Subzone with the base of bed Y 223 of the Miravetes section, which is 4,5 $\mathrm{m}$ below the base of the alpillensis Subzone. The author does not recommend to separate this topmost part of the picteti Subzone as a distinct subzone, because it is very thin, has no ammonites of its own, and can be recognized only with great difficulty even in an ammonite rich section as the one near Los Miravetes.

Perhaps a still more intriguing question is what has happened to the alpillensis Subzone in France. Because in Spain, as well as in France, the callisto assemblage is followed by ammonite assemblages that have been typified as consisting of a mixture of Berriasian and Valanginian forms, viz. the alpillensis Subzone in Spain and the Thurmanniceras otopeta Zone in France (Thieuloy, 1977b, 1979), one would be inclined to correlate the latter two. However, in the $2 \mathrm{~m}$ thick interval close to the base of the otopeta Zone, to which the overlap of the Berriasian and Valanginian ammonite ranges is restricted (Thieuloy, 1979; Hoedemaeker, 1983), appear Tirnovella pertransiens, Erdenella cf. hystricoides, Thurmanniceras otopeta, Th. salientinum, and Th. cf. allobrogicum, none of which occur in the Spanish alpillensis Subzone, but instead mark the base of the petransiens Subzone. The thin interval of overlapping ranges close to the base of the otopeta Zone correlates therefore with the basal part of the petransiens Subzone directly above the top of the alpillensis Subzone. As pointed out by the author (Hoedemaeker, 1982, 1983), the otopeta Zone of Thieuloy is essentially the same as the original pertransiens Subzone of Le Hégarat and should be abandoned as a junior synonym.

The latter correlation implies that the interval assigned to the callisto Subzone in France correlates with the uppermost $4.5 \mathrm{~m}$ of the picteti Subzone of the Miravetes section and with the total- 


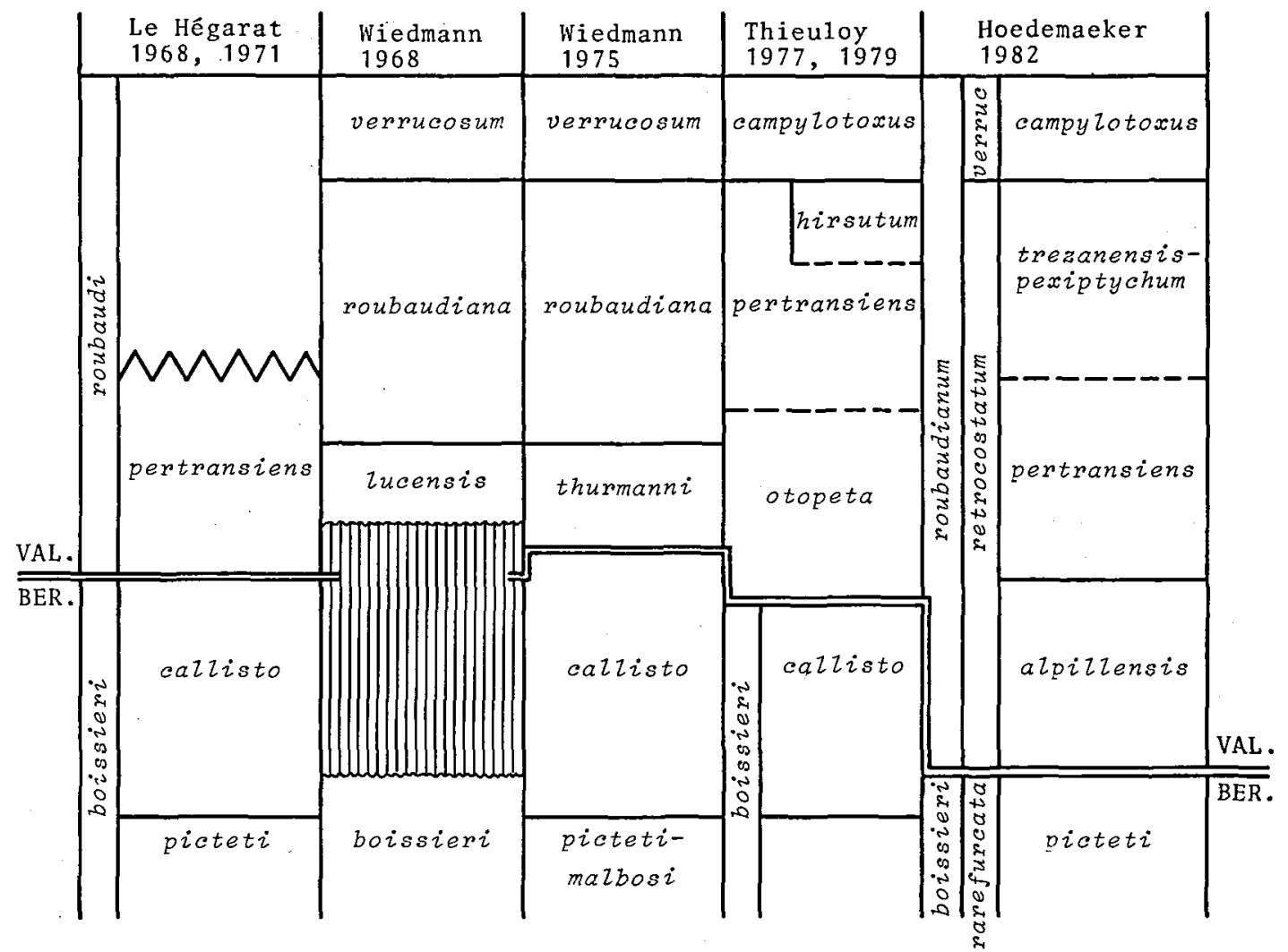

Fig. 1. Correlation of various published zonations showing the correlation of the alpillensis Subzone with the callisto Subzone. The lucensis Zone of Wiedmann (1968) was based on the type section of the Berriasian near Berrias, where the Valanginian beds are separated from the Berriasian beds by a hiatus.

ity of the $31 \mathrm{~m}$ thick alpillensis Subzone. The latter remains an undeniably real subzone with its own specific individiality. Why then has the $a l$ pillensis Subzone not been recognized in France? For several French sections, for instance the Berrias section, the existence of a hiatus along which the alpillensis Subzone is totally missing, seems to be the explanation. This explanation, however, will no longer serve for several other sections in France, for instance the La Faurie-Pusteau section (Remane \& Thieuloy, 1973), in which no trace of a hiatus has hitherto been detected.

However, Thieuloy (1966) reported the presence of Kilianella cf. roubaudiana below beds with Subthurmannia boissieri near Sarcenas (Isère). Also Le Hégarat \& Remane (1968) and Le Hégarat (1971) mention exposures at the Col de Romeyer (Drôme) and the Col du Granier (Savoi), where small Thurmanniceras and Kilianella occur together with Berriasella, and transitional forms between Tirnovella and Neocomites at outcrops near Apremont (Savoi) and the Col du Granier (Savoi). These findings indicate that the ammonite assemblage that characterizes the alpillensis Subzone does exist in France.

It is the author's interpretation that the entire interval between the French picteti and pertransiens (sensu Le Hégarat, 1971) subzones has rather undiscriminatingly been assigned to the callisto Subzone without due consideration. It seems likely that the beds assigned to the callisto Subzone in the hypostratotype of the Valanginian near Angles and in the La Faurie-Pusteau section in reality belong for the greater part (if not entirely) to the alpillensis Subzone, because it directly underlies the original pertransiens Subzone without an apparent hiatus and especially because from the latter section Kilianella cham- 
alocensis has been reported (Remane \& Thieuloy, 1973), which begins its range in the alpillensis Subzone of Spain (Hoedemaeker, 1982, 1983).

\section{Conclusions concerning the Berriasian - Valanginian boundary}

Although the alpillensis Subzone has not yet been recognized in France nor in other parts of the Tethys, it is indubitably a new, well characterizable and delimitable subzone in the Mediterranean province, which probably is also present in France. It correlates with the major upper part of the interval that in France has generally been assigned to the callisto Subzone. The lower boundary of the alpillensis Subzone should be the lower boundary of the Valanginian stage, as it contains from its base upward a rapidly diversifying assemblage of renownedly Valanginian ammonites. If the totality of the $2.5 \mathrm{~m}$ thick callisto Subzone of the stratotype of the Berriasian (Le Hégarat, 1965, 1971) correlates with the 4.5 topmost metres of the Spanish picteti Subzone, the stratotype is not violated. In view of the correlations given above the callisto Subzone had better be abandoned as a separate Subzone.

\section{Introduction with respect to the Valanginian - Hauterivian boundary}

Following the general conclusions of the 'Colloque sur Le Crétacé inférieur' (1965) the author (Hoedemaeker, 1982, p. 44, 45, 63; 1983) proposed to draw the Valanginian - Hauterivian boundary between the Saynoceras verrucosum Subzone and the Himantoceras trinodosum Subzone on the following grounds:

1. This boundary coincides with the most important break in the Neocomian ammonite faunal succession in the Mediterranean province.

2. This boundary is closest to the original lower boundary of the type Hauterivian near Neuchâtel, viz. the base of the 'couche à Astieria'.

3. This boundary corresponds with the sea level lowstand, well marked on the Vailian coastal onlap curve (Ziegler, 1982; Vail \& Todd, 1981) as 'Basal Hauterivian (126) global unconformity'.

\section{History}

In Switzerland the Neocomian (sensu stricto), for which Renevier (1873) introduced the name 'Hauterivian', was interpreted since Desor \& Gressly (1859) to begin with the 'marnes jaunes à Ammonites Astierianus'.

The finding of a specimen of the indubitably Valanginian species Saynoceras verrucosum (Sayn, 1899) in the 'couche à Astieria' near Villers-le-Lac (Doubs, France) was for Kilian (1894, $1896,1908)$ the decisive argument to transfer this bed from the Hauterivian into the Valaginian. Since then the Hauterivian stage has been interpreted all over the world to begin with the Acanthodiscus radiatus Subzone at the base of the directly overlying 'marnes bleues de Hauterive'.

Recent correlations by means of ostracods (Donze \& Thieuloy, 1975) and ammonites (Thieuloy, 1973, 1977b; Kemper et al., 1981) confirm that the 'couche à Astieria' should be correlated with the present-day Teschenites callidiscus Subzone and because of the presence of Dichotomites probably also with a part of the Himantoceras trinodosum Subzone. It has also been confirmed that the 'couche de Villers', which directly underlies the 'couche à Astieria', should be correlated with the verrucosum Subzone in the restricted sense of Thieuloy (1973).

This means however that the specimen of $S$. verrucosum in the 'couche à Astieria' occurs in an anomalous position and is probably reworked from the 'couche de Villers' in which two specimens of this species have been found (Baumberger, 1906, 1910). This also means that the main motive for the transfer of the "couche à Astieria' into the Valanginian was without foundation and that this bed could be transferred again into the Hauterivian if desired.

This alone is no argument yet to reconsider the stratigraphic position of the Valanginian Hauterivian boundary, which by tradition and convention has had a stable position for more than eighty years. However, during the 'Colloque sur le Crétacé inférieur' (1965) Busnardo (in Debelmas \& Thieuloy, 1965) made a serious attempt to change the stratigraphic position of the Valanginian - Hauterivian boundary down to a level that is better correlatable than the base of the radiatus Subzone. He introduced the 'zone à 
Lyticoceras 1.s. sp.', which he preferred, taking into account the evolution of the neocomitids, to place at the base of the Hauterivian, the more so as it contains the first crioceratids (Himantoceras Thieuloy, 1964) and as it is closest to the original base of the Hauterivian stage. The ammonites referred to as 'Lyticoceras' by Busnardo were grouped by Thieuloy (1971) into Teschenites nov. subgen. Busnardo's 'Lyticoceras zone' is equivalent to the modern trinodosum and callidiscus subzones. Since Busnardo's proposal was not opposed by any of the attendants of the colloquium and became embodied in the general stratigraphic conclusions, I have no scruples to stand for it once more (Hoedemaeker, 1982, 1983) and to press again for the Valanginian - Hauterivian boundary to be drawn between the verrucosum and trinodosum subzones. This boundary approximately correlates with the base of the $D i$ chotomites crassus Zone in northern Germany (Kemper et al., 1981).

\section{Arguments}

Busnardo was right: the boundary between the verrucosum and trinodosum subzones does coincide with one of the most important breaks in the continuity of the ammonite faunal succession of the Lower Cretaceous in the Mediterranean province. The concrete data that gave us the arguments to support the colloquium conclusions, were furnished mainly by the recent bed by bed studies of Moullade (1966), Moullade \& Thieuloy (1967a, b), and Thieuloy (1971, 1973, 1977a, 1977b, 1979) concerning the distribution of the upper Valanginian and lower Hauterivian ammonites. Their findings are not contradicted by the recent data from Bulgaria (Mandov, 1976), Czechoslovakia (Borza et al., 1980; Vašíček \& Michalík, 1981; 1983) and by my own findings in SE Spain (in preparation). Nevertheless Moullade and Thieuloy rejected the conclusions reached by the colloquium and returned to the traditional view of Kilian. Thieuloy (1977 a) even formally proposed to fix the Valanginian Hauterivian boundary - stratotype at the local appearance of $A$. radiatus at the base of bed $\mathrm{B} 35 \mathrm{~b}$ of the section $500 \mathrm{~m}$ west of la Charce (Drôme, France).

The ammonite distribution (figure 2) clearly shows the striking faunal turnover between the verrucosum and trinodosum subzones and that the typically lower Hauterivian ammonite assemblage undeniably begins in the trinodosum Subzone. The ammonite association of the trinodosum and callidiscus subzones is fundamentally different from that of the underlying verrucosum Subzone, but differs only in minor aspects (a few species) from that of the overlying radiatus Subzone.

The verrucosum Subzone (in the restricted sense of Thieuloy, 1973) can pre-eminently be qualified as a subzone in which disappearances of ammonite species greatly predominate over appearances, whereas in the trinodosum Subzone appearances of new ammonite species greatly predominate over disappearances. Between these two subzones the number of concurring ammonite species, especially the neocomitids, reaches a deep minimum, which is attended by a rapid and profound turnover of the ammonite fauna. Through this multitude of first and last appearances the advocated boundary is one of the best correlatable boundaries of the entire Mediterranean Neocomian.

The trinodosum Subzone is the cradle of many new (sub)genera, such as Teschenites, Eleniceras, Criosarasinella, Dicostella, Oosterella, Pseudoosterella (with one exception in the verrucosum Subzone, Thieuloy, 1979), Himantoceras, Phyllopachyceras, Spitidiscus, and possibly Distoloceras and Eodesmoceras. The latter has been found only in the 'marnes à Bryozoaires' near St. Croix (Vaud, Switserland), which has been deposited within the lapse of time that corresponds with the verrucosum, trinodosum, and callidiscus subzones (Donze \& Thieuloy, 1975). The Crioceratitidae, Desmoceratidae, Holcodiscidae, Endemoceratidae, and Oosterellidae (with one exception) begin their ranges in the trinodosum Subzone.

The vast majority of the typically Valanginian ammonite (sub)genera disappears in the verrucosum Subzone (in the restricted sense of Thieuloy, 1973), such as Rogersites (with one exception at the base of the trinodosum Subzone, Thieuloy, 1979), Valanginites, Dobrodgeiceras, Saynoceras, Paquiericeras, Julianites, true Neocomites (with one exception at the base of the trinodosum Subzone, Thieuloy, 1979), Substreblites, Chamalocia, and most of the representatives of Eristavites, Karakaschiceras, and 


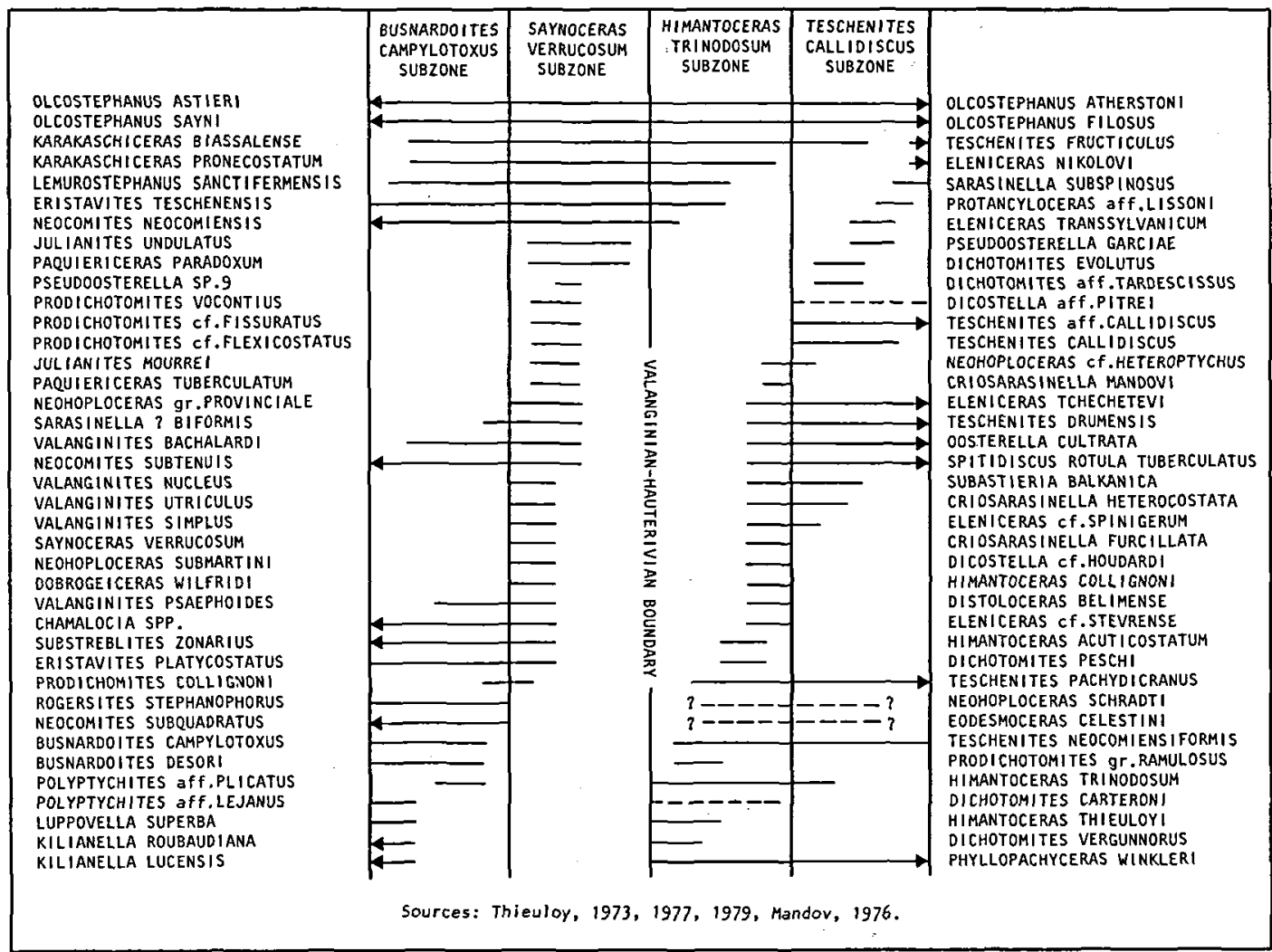

Fig. 2. Hitherto known ranges of ammonite species at both sides of the here proposed Valanginian - Hauterivian boundary. Those species of which the ranges are not known yet are left out, except for Neohoploceras schradti, whose approximate range stands for a number of species hitherto known restricted to the 'marnes à Astieria' in Switzerland (Baumberger, 1903-1910), and Eodesmoceras celestini, whose range is inferred here. Only a few of the species that die out before the verrucosum Subzone are marked.

Sarasinella. The ranges of the latter three genera cross the boundary to die out soon afterwards. Luppovella and Busnardoites have not yet been recorded from this subzone with certainty, whereas the ranges of the essentially lower Valanginian Thurmanniceras, Kilianella, and Tirnovella already came to an end in the lower part of the subjacent Busnardoites campylotoxus Subzone.

Only species of Olcostephanus, Lemurostephanus, and Bochianites have been reported to cross this boundary without any disturbance, whereas different species of Neohoploceras and Protancyloceras occur at both sides of the boundary.

The sea level lowstand that separates the Valanginian from the Hauterivian may be responsible or co-responsible for:

1. The remanie bed at the base of the D2D unit of the Speeton Clay Formation (Rawson et al., 1978; Kemper et al., 1981).
2. The condensed horizon at the top of the Claxby Ironstone Formation (Rawson et al., 1978; Kemper et al., 1981).

3. The faunal turnover between the oxigenpoor Ammovertella cellensis foraminiferal assemblage and the oxigen-rich Epistomina caracolla caracolla foraminiferal assemblage in Germany. This turnover is situated a little below the base of the crassus Zone (Kemper, 1978a; Bartenstein \& Bettensteadt, 1962) and approximately coincides with the appearance of true Dichotomites (Kemper, 1978b).

4. The condensed or missing Valanginian Hauterivian boundary beds in the subsurface of the North Sea basin and The Netherlands (Rawson \& Riley, 1982; Cotencon et al., 1975).

5. The condensed, continental, or missing Valanginian - Hauterivian boundary beds on the Russian platform, Siberia, and Canadian boreal region. 
6. The condensed 'couche de Villers' and the 'couche à Astieria' in Switzerland, which may be separated by a lacuna encompassing the top of the verrucosum Subzone and the base of the trinodosum Subzone.

The 'couche à Astieria' is the only bed from which true Dichotomites has been reported in Switzerland (Baumberger, 1908, 1910; Busnardo \& Thieuloy, 1979).

7. The so-called 'Grande Lumachelle' in the surroundings of Castellane (Alpes de Provence, France), which marks a momentary return to shallow bathymetry that ends with the transgressive phase of the radiatus Subzone (Cotillon, 1971).

\section{Conclusions concerning the Valanginian - Hauterivian boundary}

The typically Valanginian ammonite assemblage, after having suffered a severe decrease in the number of co-occurring species, suddenly makes room for a typically lower Hauterivian ammonite assemblage, which clearly makes a strong start in the trinodisum Subzone. The scarcity of ammonites at the top of the verrucosum Subzone is not a local southern French accident, but can be detected in the whole Mediterranean area. It can be ascribed to a global sea level lowstand attended by the decrease and disappearance of many ammonite biotopes (Ziegler, 1982). The boundary advocated here correlates with the worldwide lowstand of the sea level between the verrucosum-hollwedensis highstand and the important sea level rise at the base of the radiatus amblygonius subzones. It is during periods of sea level lowstand that the major faunal turnovers occur that preferably should delimit the stages and substages. The Valanginian - Hauterivian boundary had best be chosen between the verrucosum and the trinodosum subzones and the 'couche à Astieria' be transferred again into the Hauterivian, to which it originally belonged.

\section{Final remarks}

The stratigraphic position of the Berriasian - Valanginian boundary as advocated here at the entry and rapid diversification of renownedly Valanginian ammonites, was in principle acceptable for the attendants of the colloquium on the Cretaceous stage boundaries in Copenhagen 1983, but more study is required as to the exact correlation of the French $B$. callisto Subzone with the Spanish $T$. alpillensis Subzone.

The attendants of the Copenhagen colloquium had objections, however, against the here proposed position of the Valanginian - Hauterivian boundary; there was general agreement that horizons of sea level lowstands and faunal minima should preferably not be chosen for boundaries.

However, the alpillensis as well as the trinodosum Subzone represent the onsets of the Valanginian and the Hauterivian transgressions respectively, which are concomittant with the entries and rapid diversifications of new faunal elements. Whatever boundary is eventually selected, it is important that global events should be considered before selection is made.

\section{Dansk sammendrag}

På grundlag af undersøgelser over nedre kridtaflejringer i det sydøstlige Spanien er grænsedragningen mellem etagerne berriasien - valanginien og valanginien - hauterivien diskuteret. Specielt drages sammenligninger med aflejringerne i Sydfrankrig. På grundlag af ammonitstratigrafien foreslås det at drage grænsen mellem berriasien og valanginien ved basis af Tírnovella alpillensis subzonen og grænsen mellem valanginien og hauterivien ved basis af Himantoceras trinodosum subzonen. Disse to grænser svarer til to niveauer, der globalt er præget af lavt havniveau ifølge Vails havniveaukurve.

\section{References}

Bartenstein, H., \& Bettensteadt, F. 1962: Marine Unterkreide (Boreal und Tethys) in Leitfossilien der Mikropaläontologie (ed. Arbeitskreis deutscher Mikropaläontologen), 225-297. Gebrüder Bornträger. Berlin - Nikolassee.

Baumberger, E. 1903-1910: Fauna der untern Kreide im westschweizerischen Jura, 1. Teil. Abh. schweiz. paläont. Gesellsch. 30 (4) (1903); 2. Teil. Ibid.32 (3) (1906); 5. Teil. Ibid. 35 (5) (1908); 6. Teil lbid. 36 (3) (1910).

Borza, K., Gašparíková, V., Michalík, J., \& Vašíček, Z., 1980: Upper Jurassic-Lower Cretaceous sequence of the Križna - nappe (Fatric) in the Strážovce section, Strážovské Vrchy Mts. (Western Carpathians). Geologica Carpathica 31 (4), 541-562.

Busnardo, R., \& Thieuloy, J.-P. 1979: Le stratotype de Valangin. In Busnardo, R., Thieuloy, J.-P., \& Moullade, M. (eds.): Hypostratotype mésogéen de l'étage Valanginien (Sud - Est de la France) I. Introduction. Les Stratotypes français. Edition C. N. R. S. 6, 11-15.

Colloque sur le Crétacé inférieur 1965. Mém. Bur. Rech. Géol. Min. 34. 
Cotençon, A., Parant, B., \& Flacelière, G. 1975: Lower Cretaceous gas - fields in Holland. In Woodland, A. W. (ed.): Petroleum and the continental shelf of north-west Europe 1 (Geology), 403-412.

Cotillon, P. 1971: Le Crétacé inférięr de l'are subalpin de Castellane entre l'Asse et le Var. Stratigraphie et sédimentologie. Mém. Bur. Rech. Géol. Min. 68, I-XVII, 1-313.

Debelmas, J., \& Thieuloy, J.-P. 1965: Etage Hauterivien. In Colloque sur le Crétacé inférieur (Lyon, 1963). Mém. Bur. Rech. Géol. Min. 34, 85-96.

Desor, E., \& Gressly, A. 1859: Etudes géologiques sur le Jura neuchâtelois. Mém. Soc. Sci. nat. 4, 1-159.

Donze, P., \& Le Hégarat, G. 1965: Les dépôts de la limite Berriasien - Valanginien dans la stratotype du Berriasien de Berrias (Ardèche) et dans la region avoisinante. C. $R$. Acad. Sc. Paris 260 (9), 3707-3709.

Donze, P., \& Thieuloy, J.-P. 1975: Sur l'extrême condensation du Valanginien supérieur dans le Jura neuchâtelois, en particulier dans le stratotype de Valangin, et sa signification dans l'ensemble des formations valanginiennes du Sud-Est de la France. C. R. Acad. Sc. Paris 280 (D), 16611664.

Hoedemaeker, Ph. J. 1982: Ammonite biostratigraphy of the uppermost Tithonian, Berriasian, and lower Valanginian along the Río Argos (Caravaca, SE Spain). Scripta Geol. $65,1-81$.

Hoedemaeker, Ph. J. 1983: Reconsideration of the stratigraphic position of the boundary between the Berriasian and the Nemausian (= Valanginian sensu stricto). Zitteliana 10, 447-457.

Kemper, E. 1978a: Die Beckenfacies der Unterkreide im nördlichen Vorland des Wiehengebirges. In Kemper, E., Ernst, G., \& Thiermann, A.: Excursion A1. Die Unterkreide im Wiehengebirgsvorland bei Lübbecke und im Osning zwischen Bielefeld und Bevergern. Excursionführer des Symposiuns deutsche Kreide Münster, A1/14-A1/26.

Kemper, E. 1978b: Einige neue, biostratigraphisch bedeutsame Arten der Ammoniten-Gattung Dichotomites (NWDeutschland, Obervalangin). Geol. $J b$. A 45, 183-253.

Kemper, E., Rawson, P. F., \& Thieuloy, J.-P. 1981: Ammonites of Tethyan ancestry in the early Lower Cretaceous of north-west Europe. Palaeontology 24 (2), 251-311.

Kilian, W. 1894: Quelques réflexions sur le parallélisme du Valanginien jurassien avec le Crétacé inférieur de la région delphino - provençale. Bull. Soc. géol. France (3) 22, compte-rendu des seances 2: XIV-XV.

Kilian, W. 1896: Notice stratigraphique sur les environs de Sisteron et contribution à la connaissance des terrains secondaires du sud-est de la France. Bull. Soc. geol. France (3) 23 (1895), 659-803.

Kilian, W. 1908: Sur l'age de la couche jaune à Astieria du Jura neuchâtelois. Bull. Soc. géol. France (4) 8, 270.

Le Hégarat, G. 1965: Stratigraphie et macrofaune. In Busnardo, R., Le Hégarat, G., \& Magné, J.: Le stratotype du Barriasien. In Colloque sur le Crétacé inférieur (Lyon, 1963). Mém. Bur. Rech. Géol. Min. 34, 9-16.

Le Hégarat, G. 1971: Le Berriasien du sud-est de la France. Doc. Lab. Géol. Fac. Sc. Lyon 43, 1-576.

Le Hégarat, G., \& Remane, J. 1968: Tithonique supérieur et Berriasien de l'Ardèche et de l'Hérault. Corrélation des ammonites et des calpionelles. Geobios 1, 7-69.

Mandov, G. 1976: L'étage Hauterivien dans les balkanides occidentales (Bulgarie de l'ouest) et sa faune d'ammonites. Annuaire Univ. Sofia Fac. Géol. (Géologie) 67, 11-99 (in Bulgarian).

Moullade, M. 1966: Etude stratigraphique et micropaléontologique du Crétacé inférieur de la 'Fosse Vocontienne'. Doc. Lab. Géol. Fac. Sci. Lyon 15, 1-369.
Moullade, M., \& Thieuloy, J.-P. 1967a: Nouvelle contribution à l'étude biostratigraphique de l'Hauterivien vocontion: caractérisation et extension de la zone à radiatus. CompteRendu sommaire Soc. géol. France 1967 (2), 46-48.

Moullade, M., \& Thieuloy, J.-P. 1967b: Les zones d'Ammonites du Valanginien supérieur et de l'Hauterivien vocontiens. Compte-Rendu sommaire Soc. géol. France 1967 (6), 228-230.

Rawson, P. F., \& Riley, L. A. 1982: Latest Jurassic - Early Cretaceous events and the 'Late Cimmerian Unconformity' in North Sea area. Amer. Assoc. Petr. Geol. Bull. 66 (12), 2628-2648.

Rawson, P. F., et al. 1978: A correlation of Cretaceous rocks in the British Isles. Geol. Soc. London, Special Report 9, 1-70.

Renevier, E. 1873-1874: Tableau des terrains sédimentaires qui représentent les époques de la phase organique. Bull Soc. vaud. Sc. nat. 12 (1873), tabl. IV. Ibid. 13 (1874), 218-252.

Remane, J., \& Thieuloy, J.-P. 1973: Coupe A. IV-I: La FauriePusteau. In Livret - Guide des excursions, Colleque sur la limite Jurassique - Crétacé. Doc. Lab. Geol. Fac. Sc. Lyon, Hors série 1, 101-105.

Sayn, G. 1889: Sur quelques ammonites de la couche à Holcostephanus Astieri. Archives Sc. phys. nat. Genève (3) 22.

Thieuloy, J.-P. 1966: Leptocères berriasiens du massif de la Grande - Chartreuse. Trav. Lab. Géol. Grenoble 42, 281295.

Thieuloy, J.-P. 1964. Un Céphalopode remarquable de I'Hauterivien basal de la Drôme: Himantoceras nov. gen.. Bull. Soc. géol. France (7) 6, 205-213.

Thieuloy, J.-P. 1971. Réflexions sur le genre Lyticoceras Hyatt, 1900 (Ammonoidea). C. R. Acad. Sc. Paris 272 (D), 22972300.

Thieuloy, J.-P. 1973: The occurrence and distribution of boreal ammonites from the Neocomian of southeast France (Tethyan Province). In Casey, R., \& Rawson, P. F. (eds.): The Boreal Lower Cretaceous. Geol. Jour. Special Issue 5, 289-302.

Thieuloy, J.-P. 1977a: La zone à callidiscus du Valanginien supérieur vocontien (Sud-Est de la France). Lithostratigraphie, ammonitofaune, limite Valanginien - Hauterivien, correlations. Géol. Alpine 53: 83-143.

Thieuloy, J.-P. 1977b: Les ammonites boréales des formations néocomiennes du Sud-Est français (Province subméditerranéenne).I Geobios 10 (3), 395-461.

Thieuloy, J.-P. 1979: Les ammonites. Description des espèces indices et de quelques autres formes fondamentales. In Busnardo, R., Thieuloy, J.-P., \& Moullade, M. (eds.): Hypostratotype mésogéen de l'étage Valanginien (Sud-Est de la France) III. La faune. Les Stratotypes français. Edition C. N. R. S. 6, 37-57.

Vail, P. R., \& Todd, R. G. 1981: Northern North Sea Jurassic unconformities, chronostratigraphy and sea-level changes from seismic stratigraphy. Petroleum geology of the continental shelf of North-West Europe, 216-235.

Vašiček, Z., \& Michalík, J. 1981: Remarks to the Lower Cretaceous stratigraphy and paleogeography of the northern part of the Western Carpathians. Geologica carpathica 32 (1), 143-153.

Vašíček, Z., Michalík, J., \& Borza, K. 1983: To the 'Neocomian' biostratigraphy in the Križna - Nappe of the Strážovské Vrchy Mountains (Northwestern Central Carpathians). Zitteliana 10, 467-483.

Ziegler, P. A. 1982: Geological atlas of Western and central Europe (ed. Shell Intern. Petroleum Mij BV), 1-130. Drukkerij Verwey BV, Mijdrecht. 